\title{
The Development of Personal-Cooperative Model in Building the Reading Comprehension Skills
}

\author{
*Siti Rochmiyati, Postgraduate Student of Universitas Negeri Yogyakarta, Yogyakarta, Indonesia \\ Universitas Sarjanawiyata Tamansiswa, Yogyakarta, Indonesia, rochmiyati_atik@ustjogja.ac.id \\ Burhan Nurgiyantoro, Universitas Negeri Yogyakarta, Yogyakarta, Indonesia \\ Kastam Syamsi, Universitas Negeri Yogyakarta, Yogyakarta, Indonesia \\ * Corresponding Author
}

\begin{abstract}
This study aims to identify the need for developing a reading comprehension personalcooperative-based learning model for junior high school students, build learning models and their learning tools, to test the validity of the results of the learning model by experts and users, testing the effectiveness of the learning model. This study used the Research and Development (R\&D) method. There are three stages, namely (1) The exploration stage, (2) The development stage, (3) The testing stage. The number of teachers who were the subject of the study was 20 Indonesian junior high school teachers. There are 32 students for interviews and 317 students for data collection used a questionnaire. The development of the reading comprehension personal-cooperative-based learning model is equipped with four products, namely (1) a conceptual guidebook on reading comprehension learning model, (2) guidelines for reading comprehension personal-cooperative learning model, (3) reading comprehension learning materials, and (4) reading box and answer key box. The results of the feasibility of products of the reading comprehension personal-cooperative-based learning model are declared to be feasible by expert and user validators with an excellent category. Personal-cooperative based reading comprehension learning model is effective in improving students' reading comprehension ability.
\end{abstract}

Keywords: Model development, Personal-cooperative, reading comprehension, Reading skills

Received: 16.11.2020 Accepted: 05.12.2020 $\quad$ Published: 17.01.2021

\section{INTRODUCTION}

The purpose of language learning is essential so that students have communicative competence. This communicative competence is reflected in the activities of students in communicating. Communication activities can be receptive and productive, can use spoken and written language. Delivering using language requires listening, speaking, reading, and writing skills. Among the four language skills, the most widely performed activity in the learning process at school is reading. Reading is a complex process (Crawley \& Mountai, 1995). Reading activity that aims to get information is reading comprehension.

Reading comprehension involves the process of understanding opinions or messages conveyed by the author (May \& Rizzardi, 2002). Reading comprehension is also an act of linking one idea with another. When there is a word in the text that is difficult to interpret, a critical reader will connect to see it in the context of sentences and paragraphs. Besides being complicated, reading is also a multidimensional process. Reading comprehension is a high-level cognitive process (Perfetti \& Stafura, 2014). The core elements are the source of knowledge, cognitive processes, and the interaction of both. Reading comprehension is a complex cognitive process of symbols to obtain meaning.

Hidayah (2012) research shows that the social environment of the school, which is not conducive, also contributes to the low reading comprehension of students. Another cause is the lack of support from teachers and the literacy environment in schools, as well as various inadequate means of infrastructure and learning media for reading. Likewise, Mustofa's study (Mustofa, 2012) concludes that Indonesian reading habits are still low. Some of the factors that influence it are the low availability of reading infrastructure and minimal parental support.

Concerns about students' reading comprehension skills do not only occur in Indonesia. Kissau \& Hiller (2013) described in his research in the United States and Germany. For this reason, it is necessary to look for strategies for learning to read the right understanding. The study found that reading content was significant and had to be following student life. This is where learning with a personal model that prioritizes the needs and interests of students is needed. This is in line with the research of Cannor \& Morrison (2016), who develop personalized learning for each child. The gap in reading comprehension skills in America due to failure to take into account the strengths and weaknesses brought by students in school. 
Classical learning models are less able to provide maximum space for students to develop their abilities. There is a need for a learning model that gives broader rights to students so that the individual children's potential can develop optimally. Classical learning is more teacher-centered and top-down. Sadeghi and Moslehpour (2014) suggested that students be given access to be able to search individually and be discussed in groups. The elaboration of personal and social models with cooperative learning is vital to develop (Cannor \& Morrison, 2016).

The personal learning model is learning that is very focused on the individual self-development of students. In learning the personal model, the teacher must strive to create conducive classroom conditions, so that each student feels free in learning and developing himself optimally both intellectually and emotionally. The Zone of Proximal Development (ZPD) theory developed by Lev Vygotsky (1896-1934). Bozhovich (2009) says there is a difference between what students can do without help and what they can do with help. This ZPD concept describes a gradual area between the level of performance of children independently and the level of performance of children with assistance. A child's skills and understanding can emerge if the child is involved in interactions with knowledgeable others. Therefore, for optimal personal and social development models need to be elaborated.

Personal models refer to student-centered learning as individuals with needs, rights, and capacities that relate to student responsibilities, which are an integral part of the learning and teaching process (Coleman \& Klapper, 2005). In the personal model, the learning technique used is independent learning, which is sometimes equated with the terms autonomous learning, self-directed learning, open learning self-access, or self-instruction, and independent learning (Mota, 2014).

Pearman's research found that after students independently interacted with storybooks, there were still many students who had difficulty reading comprehension. Learning continues with class discussion. They need to discuss with more capable peers (Pearman, 2008). It means, learning with a personal model needs to be elaborated with group discussion in a social model.

The purpose of cooperative learning is to create a situation that individual success is determined or influenced by the group (Slavin, 1994). In the collaborative learning model, Johnson \& Johnson (1999) suggests there are five elements, namely: (1) positive interdependence, (2) individual responsibility, (3) face to face, (4) communication between members, and (5) group processing. In cooperative learning to learn, learning material is said to have not finished learning if one of the friends in the group has not mastered the lesson material. Therefore, cooperative learning as a form of learning social models needs to be developed in accordance with the principles of cooperative learning.

Several reading learning media can be used and provide personal space as well as the development of social attitudes. For example, a reading device followed by a quiz. However, the media usually do not have to be measured beforehand the suitability of the level of readability of the discourse with the user. Lehr (2013) says one of the difficulties in reading comprehension is the quality of reading material. The media that the reader adjusts the level of readability is the reading box. The reading box equipment consists of a box that contains a complete set of reading texts with a list of questions and an answer key as well. Therefore, in this study, the application of personal-cooperative models in learning to read comprehension using the Reading Box media.

\section{METHODS}

This study used the Research and Development (R\&D) method. Educational research and development is a strategy for developing effective educational products that can be used as alternatives to overcome learning problems (Gall et al., 2003). In the research stage from R\&D, used mixed methods with exploratory design. Exploratory design procedures are implemented using Exploratory Sequential Design (Creswell, 2008).

This R\&D research procedure uses a combination of the Gall, Borg \& Gall (2003) and Sukmadinata (2012) models. R\&D research into three stages, namely (1) The exploration stage: research and information collecting, planning, and developing preliminary forms of the product; (2) The development stage: initial field testing and main product; (3) The testing stage: main field testing, operational product revision, operational field testing, final product revision, and dissemination and implementation

\section{Sample of Research}

The exploration stage, research subjects in this stage are the teacher and students. The number of teachers who were the subject of the study was 20 Indonesian junior high school teachers coming from junior high schools in Kulonprogo, Bantul, Sleman, Gunungkidul, and Yogyakarta City. Student subjects consisted of two groups, namely 32 students for interview subjects and 317 students for data collection using a 
questionnaire. Students come from four junior high schools, namely: (1) SMPN 1 Kasihan Bantul, (2) SMPN 4 Wates, Kulonprogo, and (3) SMPN 2 Ngemplak Sleman and SMPN 1 Sleman.

The development stage, product validation, is done by experts and by users. Three experts carry out product validation, namely: 1) Prof. Dr. Suminto A. Sayuti (literary and learning expert); 2) Dr. Hartono (experts in language and literature learning); 3) Dr. Wijaya Heru Santosa (expert evaluation and media learning language and literature). Indonesian learning experts from teachers are 1) Harini Catur Utami, M.Pd (Indonesian language teacher from Sleman Regency); 2) Tri Warsiati, M.Pd (Indonesian language teacher from Kulonprogo Regency); 3) Siti Zukhanah, M.Pd (Indonesian language teacher from Bantul Regency).

In the testing stage, research subjects at the limited scale trial stage were Indonesian language teachers and students from SMPN 2 Ngemplak, Sleman regency. The trial was conducted in 7th grade, with 32 students. The research sample at the broader scale trial stage was students from SMPN 4 Wates, Kulonprogo regency. There are two groups of students of 7 th grade, namely 31 students as an experimental group and 30 students as a control group.

\section{Instrument and Procedures}

The exploration stage is to obtain a description of the problem of reading comprehension learning that is relevant to the Personal-Cooperative model in junior high school. At the exploration stage, it is carried out by reviewing theory, gathering information, and conducting need assessment as a process of identifying, documenting, and justifying the gap between what happens and what will be generated through determining the priority scale of each need. At this stage, the stages of information gathering, identification of gaps, performance analysis (teacher and student) are carried out, identifying constraints and their sources, identifying priorities and goals, and determining problems.

Structured interviews were conducted with teachers and students from SMPN 1 Kasihan Bantul, SMPN 4 Wates Kulonprogo, and SMPN 1 Sleman. Observations carried out planned and controlled while the learning process of reading comprehension takes place. An observation guide sheet guides this activity. Questionnaire students 'perceptions of reading comprehension learning in junior high school in this study were divided into three components, namely (1) questionnaire of students' attitudes of reading comprehension learning materials, (2) learning models of reading comprehension, and (3) learning media for reading comprehension. Document analysis is done by analyzing and reviewing documents related to students' reading comprehension documents and learning media used in learning to read comprehension that has been used at school.

The development stage is carried out to compile draft a reading comprehension PersonalCooperative-based learning model in the Indonesian language in junior high school. The steps in the development phase of this model are: (1) the drafting of a Personal-Cooperative-based learning reading comprehension model in junior high schools based on theoretical studies and need analysis; (2) validation by language teaching experts; (3) product improvement based on expert input; (4) presentation of Personal-Cooperative-based understanding learning models in the classroom; (5) product validation by the user and observing the results of the presentation of the Personal-Cooperative reading comprehension learning model; (6) improvement of the Personal-Cooperative-based understanding learning model product.

There are four sets of learning model products developed, namely (1) Personal-Cooperative learning model manuals, (2) Personal-Cooperative model learning planning guides, (3) reading comprehension teaching materials with Personal-Cooperative models, and (4) devices Reading Box. The product set was validated by experts using instruments in a semi-closed form.

The instrument validation for model manual consists of 15 items, including aspects of content eligibility (5 items); feasibility aspects of presentation (4 items); linguistic aspects (3 items); Graphic aspects (3 items). Instruments of learning planning book validation include Identity; aspects of competencies, indicators, and learning objectives; material aspects, learning syntax aspects; aspects of media and learning resources; assessment aspects. The validation instrument of the personal-cooperative learning planning book consists of 14 items. The validation instrument for teaching reading comprehension with the personal-cooperative model consists of 17 questions. The instrument validation box consists of 9 items.

Data collection techniques in this stage by observation, documentation, tests, and interviews. Data validity checking techniques with triangulation, selection of collaborator teachers, member checks, respondent validation, and Focus Group Discussion (FGD). 
The model testing stage to produce effective reading comprehension models based on personalcooperative learning. The research design used quantitative research. The research procedure was an experimental study with a pretest-posttest control group design.

\section{Data Analysis}

Data analysis uses descriptive statistics and comparative tests. A descriptive study was conducted to describe the results of reading comprehension learning, both in the control class and the experimental class. The comparative analysis is performed to analyze the average comparison of the effects of reading comprehension skills in the control class and the experimental class using a t-test.

\section{RESULTS}

\section{Initial Product Development}

Document analysis shows the ability to read the understanding of each student is not owned by the teacher. Even if there has been material on the ability to read comprehension, the data is only held by students in student notebooks. Similarly, the progress in the reading comprehension ability of each student has not been well documented. The books that are used as learning resources for reading comprehension consist of textbooks and student worksheets. Based on document analysis, there are two types of books, namely mandatory books and enrichment books. Learning implementation plan developed by teachers found a variety of learning methods and media. One method is discussion. However, the discussion method used is only general, it does not seem the type of cooperative learning that is used. The steps or syntax of the discussion are also not specified. The responsibility of each member in the group also does not exist. Learning media for reading comprehension that is used accordingly with those in textbooks or worksheets. Learning media and learning resources for reading comprehension used by teacher's only textbooks, worksheets, and sometimes from newspapers, magazines, and only occasionally use sources from the internet.

Observations carried out during the learning process with the discussion method. The teacher uses the conventional group discussion method, meaning that the grouping and implementation is only with conventional discussion. Conventional discussion in question is a discussion model in which the grouping does not pay attention to the heterogeneity of students, both in terms of abilities and gender and responsibilities only in groups. The role of each group member is not optimal and the division of responsibilities of each member has not been designed. Only students who are bright are more active when the presentation is more focused on children who are smart and dare to speak in front of the class. Sources of reading more often use textbooks that all students in the same class. In addition to books, student work twins are also used. The use of internet media is not done because internet access is not available optimally.

Interviews with teachers are done individually, while interviews with students are done in groups and informally. So that students feel they are not being interviewed in the context of research. The results of interviews with teachers revealed that almost all teachers did not have documents on the ability to read each student's comprehension. The learning facility for reading comprehension, which is explicitly given to students based on the students' condition, is not well prepared. The cooperative learning model implemented by teachers does not fully refer to the true nature of cooperative learning. Teachers still often use the conventional discussion model because it is easier to implement. The division of tasks in groups has been carried out, but the planting and distribution of individual responsibilities are not optimal. The grouping model during group discussion also does not accommodate heterogeneity in students' reading comprehension ability. The results of interviews with students note that students can understand the ability to read and want the teacher to understand and help develop reading ability. Their motivation to improve personal reading skills is also quite good. Students expect that learning is more varied, not classical. In fact, students are very happy if they are given the freedom to find their own reading.

Based on the results of the needs analysis, the products needed and developed are (1) manual books, (2) learning plan guides, (3) teaching materials, (4) reading box.

Table 1. Validity for manual books of personal-cooperative model

\begin{tabular}{|l|c|c|c|c|}
\hline \multirow{2}{*}{ Assessment Aspects } & \multicolumn{2}{|c|}{ Experts } & \multicolumn{2}{c|}{ Users } \\
\cline { 2 - 5 } & $\begin{array}{c}\text { Number of } \\
\text { Items }\end{array}$ & Score & $\begin{array}{c}\text { Number of } \\
\text { Items }\end{array}$ & Score \\
\hline Content eligibility & 5 & 4.33 & 5 & 4.47 \\
\hline Presentation eligibility & 4 & 4.33 & 4 & 4.33 \\
\hline
\end{tabular}




\begin{tabular}{|c|c|c|c|c|}
\hline Language & 4 & 4.55 & 3 & 4.44 \\
\hline Graphics & 4 & 4.33 & 3 & 4.44 \\
\hline Total & 15 & 4.38 & 15 & 4.42 \\
\hline
\end{tabular}

The validation results by experts for the Model Guidebook product obtained an average of 4.38 in the excellent category. The results of user validation were in the excellent category, with an average of 4.42. Four aspects show a very good category, which means the product can be used.

Table 2. Validity for learning plan guide of personal-cooperative model

\begin{tabular}{|l|c|c|}
\hline \multicolumn{1}{|c|}{ Assessment Aspects } & Experts & Users \\
\hline Adequacy and clarity of the learning plan identity & 4.33 & 4.66 \\
\hline Clarity of competence to be achieved & 4.33 & 4.66 \\
\hline Matching goals between learning and achieving competence & 4.33 & 4.33 \\
\hline $\begin{array}{l}\text { Adequacy of learning resources following personal and social } \\
\text { development }\end{array}$ & 4.33 & 4.00 \\
\hline $\begin{array}{l}\text { Appropriate syntax of learning stage I with a personal-cooperative } \\
\text { model }\end{array}$ & 4.33 & 4.33 \\
\hline $\begin{array}{l}\text { Appropriate syntax of learning stage II with a personal-cooperative } \\
\text { model }\end{array}$ & 4.66 & 4.66 \\
\hline Completeness of the model Personal-Cooperative elements & 4.33 & 4.33 \\
\hline Adequacy of time allocation for each learning stages & 4.33 & 4.33 \\
\hline The learning steps consist of developing student character & 4.33 & 4.33 \\
\hline Adequacy of learning resources/references & 4.33 & 4.33 \\
\hline $\begin{array}{l}\text { Appropriate selection of media and learning resources with personal- } \\
\text { cooperative model }\end{array}$ & 4.66 & 4.66 \\
\hline $\begin{array}{l}\text { The accuracy of the selection of techniques and forms of assessment } \\
\text { instruments }\end{array}$ & 4.33 & 4.33 \\
\hline Completeness of assessment instruments & 4.66 & 4.00 \\
\hline $\begin{array}{l}\text { Completeness of attainment of aspects of attitudes, skills and knowledge } \\
\text { in comprehensively }\end{array}$ & 4.33 & 4.33 \\
\hline \multicolumn{1}{|c|}{ Average } & 4.41 & 4.36 \\
\hline
\end{tabular}

The validation results from the expert validator obtained an average of 4.41 in the excellent category. The mean value of the user validator in the learning plan book is 4.36, depending on the very good category.

Table 3. Validity for reading box

\begin{tabular}{|c|c|c|c|c|}
\hline \multirow{2}{*}{ Assessment Aspects } & \multicolumn{2}{|c|}{ Experts } & \multicolumn{2}{c|}{ Users } \\
\cline { 2 - 5 } & Number of Item & Score & Number of Item & Score \\
\hline Reading Box & 7 & 4.38 & 7 & 4.38 \\
\hline Answer Key Box & 2 & 4.33 & 2 & 4.50 \\
\hline Total & 9 & 4.37 & 9 & 4.41 \\
\hline
\end{tabular}

The results of expert validation on the Reading Box products in the excellent category with an average of 4.37. The results of the user validation of the products of the Reading Box and KK Answer are in the very good category with an average of 4.41 .

A limited scale product trial is carried out on each element in the model, as shown in Figure 1. 


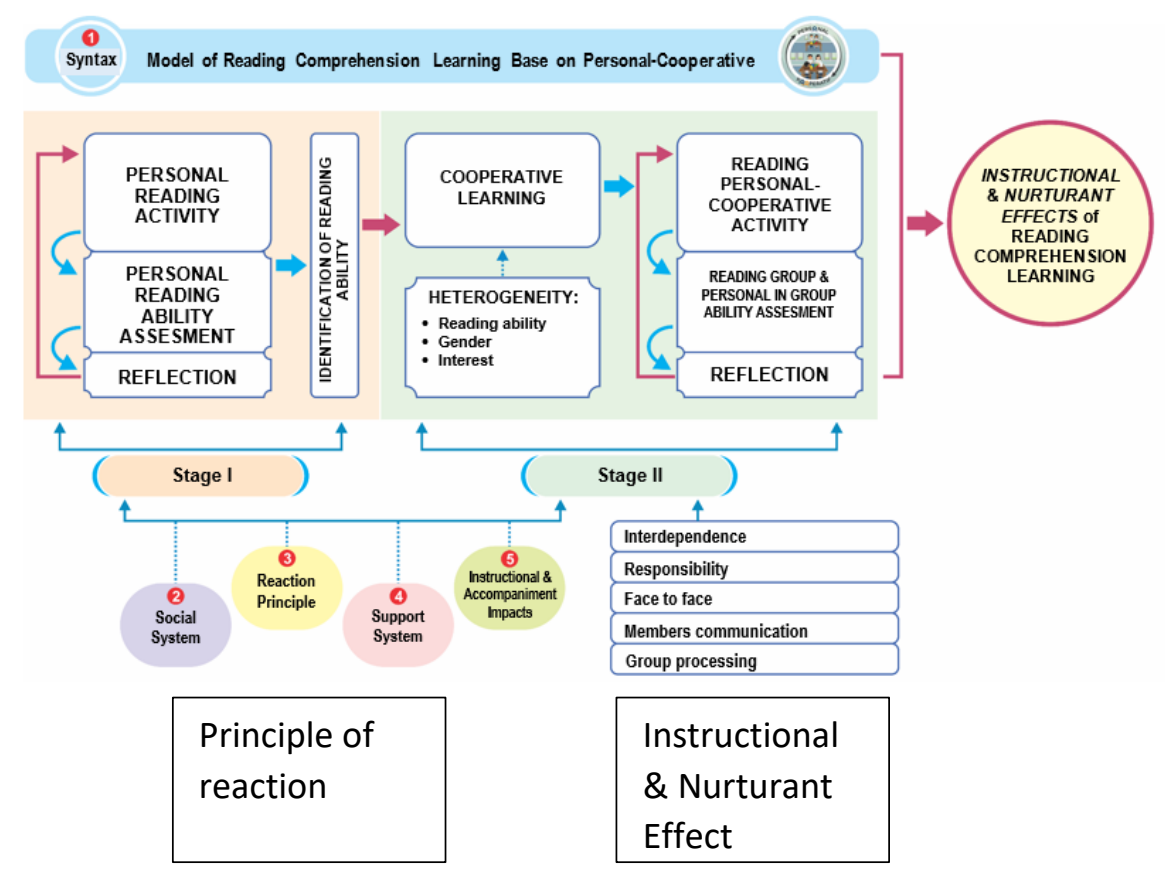

\section{Figure 1: The Syntax of Model of Reading Comprehension Learning Base on Personal-Cooperative}

The learning syntax in Figure 1 consists of two stages of learning. Every step of learning always pays attention to the elements of other learning models, namely aspects of the social system, the principle of reaction, support systems, as well as instructional and accompaniment impacts. Phase I syntax is an independent reading comprehension activity with the personal model while taking into account other elements of the model. After evaluating the ability to read comprehension, reflection activities are held to improve the next learning. The results of stage I reading comprehension assessment were identified for consideration of phase II learning.

Syntax Phase II is in the form of learning activities for reading comprehension with cooperative learning in social interaction models and still paying attention to other model elements. Activity reading comprehension students' with the Personal-Cooperative model. Cooperative learning techniques can be with the jigsaw, Two Stay Two Stray (TSTS), or other cooperative learning techniques. The division of groups in cooperative learning pays attention heterogeneity both the level of reading comprehension ability (results Stage I), gender, and student interests. When implemented the syntax of cooperative learning, four other elements of the learning model must be applied. In addition, cooperative principles learning is always applied, namely (1) interdependence, (2) responsibilities, (3) face to face, (4) communication between members, and (5) group processing-activity reading comprehension students' with the Personal-Cooperative model. Tasks in cooperative learning still have individual responsibilities, and there are tasks as a group. Everything is in group processing. The assessment also includes group and personal assessments within the group. Reflection is carried out with students and is used as consideration for improvement in subsequent learning.

In this manual, a discussion of grouping is also described by applying the principles of cooperative learning. In this study, the technique used with the jigsaw. Therefore, there is a division of "Initial" and "Expert" groups, as in Figure 2. 


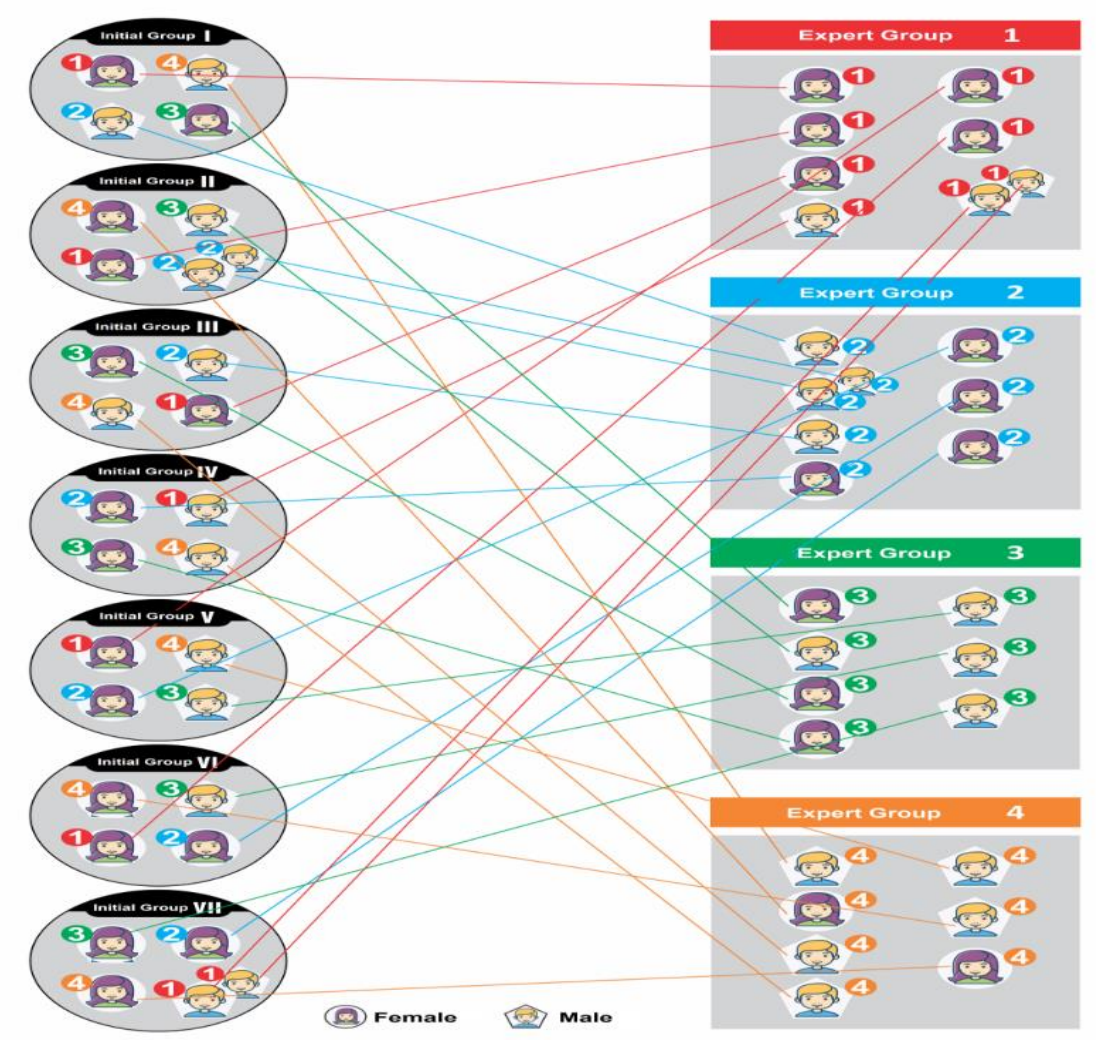

Figure 2. Model of Transfer from Origin to Expert Groups

Larger scale trials through experimental research procedures with a pretest-posttest control group design. An experimental group with a personal-cooperative reading comprehension learning model with a Reading Box. The control group with the learning model of reading comprehension with the discussion model with the reading material available in textbooks is usually used by the teachers. The research instrument at this stage was a reading comprehension test that had been developed in the Reading Box in the form of an objective multiple-choice examination with four alternative answers.

The results of the $t$-test analysis showed that there was a significant difference $(t$ statistic $=3.957$, $\mathrm{p}<0.05$ ) between the reading comprehension ability of students who studied with the PersonalCooperative learning model and students who learned to use classical learning with textbooks commonly used by teachers. The mean of the control group was 81.43, and the experimental class was 88.61. The average of the experimental group was higher than the mean of the control group.

\section{DISCUSSION}

\section{The exploration stage}

The reading comprehension learning in several schools is still classically. This learning tends to generalize the conditions and abilities of students. Learning strategies and reading materials used in a uniform class, such as those in textbooks or student worksheets. Carl Rogers (1971) argues that student self-development should be central. The process of reading comprehension is a process experienced by individual readers. Students can read different understandings and interests. So the model used should pay attention to needs, rights, and be student-centered (Coleman \& Klapper, 2005).

The result of Cannor \& Morrison (Cannor \& Morrison, 2016) research in America indicates that reading learning needs to be personalized by paying attention to students' strengths and weaknesses. This is to decrease the gap between students who have high reading skills and the low one. Such a model is called a personal model. Personal models through independent learning are often termed independent learning, independent learning, or independent learning. Learning models provide separate space for students to be developed in accordance with their personal development (Mota, 2014). Teachers need to provide appropriate facilities for students who can develop to the maximum and students who can provide services.

The Zone of Proximal Development (ZPD) theory considers that there is a gradual area between the level of performance of children independently and the level of performance of children when involved in interactions with knowledgeable others (Bozhovich, 2009). The process of reading comprehension is 
indeed carried out by individuals, but efforts to improve their abilities need to interact with others through discussion and cooperation (Pearman, 2008). Therefore, the personal model is elaborated with the social model, which is a model that creates synergy to get positive collective energy. Successful comprehension requires readers to make meaning out of what they read. The study affirms the importance of automaticity in word recognition and comprehension strategies in contributing to reading comprehension (Yildirim et al., 2020).

Social interaction models can be done with a variety of models, such as a model of partners in learning, group investigation, role-playing, or with a model of jurisprudential inquiry. Patel (Patel, 2013) divides strategy into social interaction models into three, namely group projects, group discussions, and cooperative learning. The social model emphasizes a cooperative attitude.

Based on the conditions of learning and some research results, learning to read comprehension that has not been maximized results are overcome by learning models that elaborate personal models and social interactions. The model is called the personal-cooperative model. This personal-cooperative model is in accordance with Karl (Karl, 2009) research which says that students need to learn to compete personally in the umbrella of cooperation. This model is also in accordance with Johnson \& Johnson's (Johnson \& Johnson, 2002) model of learning together and alone.

Cooperative learning that teachers do is still conventional, not yet applying the principles of cooperative learning. Individual responsibility in group processing has not been optimized. Discussion learning still does not pay attention to heterogeneity and individual responsibility in group processes. Lie (Lie, 2010) mentioned that cooperative learning is not just group learning, but there must be positive interdependence and individual responsibility in group processing.

Based on interviews with teachers from the districts of Bantul, Kulonprogo, and Sleman that the elements of the learning model that are understood are only learning syntax. Teacher perception is still limited to syntax. Other elements of the model such as the social system, the principle of reaction, the support system, and the instructional and accompaniment impacts are not yet understood, so when applying a model, only the syntax of the model is considered. Learning with a personal model has been carried out, but not yet maximized. Offering material, methods, media, and techniques to be used by students is rarely done. Teachers more often carry out learning in accordance with the plans that have been prepared at the beginning of the semester. Reading material always uses text in a text book sometimes added with other references.

Learning with conventional discussion because most teachers do not comprehensively comprehend the true principles of cooperative learning. The division of groups is rare by paying attention to gender and equal distribution of students' reading comprehension abilities. The division of groups is more often done by grouping students who are adjacent to their seats. The principle of cooperative learning with interdependence and individual responsibility in group processing has also not been addressed. The task of discussion is group, as a result the discussion activities are still dominated by smart students. Similarly, when presenting the results of the discussion. Bieńkowska, Polok, \& Sutkowski (2020) concluded that there was a correlation between age, sex and seniority with attitudes towards the application of creative approaches.

Based on the needs analysis at the exploration stage above, the syntax in the Personal-Cooperative model is developed by paying attention to the elements of the model in addition to the syntax and the principles of the learning model of the personal model and the cooperative model. The teachers also suggested that the personal-cooperative learning model training not only be followed by the model teachers or teachers in the sample schools, but also by other teachers.

The syntax of the personal-cooperative model includes two stages, namely Phase I with guided independent learning and Phase II with cooperative learning. Reading sources need to vary, not only from textbooks or student work sheets. Tavakoli (2013) examined the development of reading comprehension skills with the use of print media. Eker (2014) through experimental research proves that students' reading comprehension skills with the media are significantly higher than those who only use textbooks. Therefore, reading resources are developed that can be used both in personal and social (cooperative) models, namely the Reading Box. The application of the personal-cooperative model needs clear guidance. For this reason, in the application of this model a conceptual guidebook, learning tool, teaching material, and learning media for reading comprehension are developed.

\section{The development stage}

Research questions at the development stage are about the syntax of learning and the results of the validation of development products. Learning syntax is one element of the model. Other factors in the form of social systems, reaction principles, support systems, and instructional measures (both direct and accompaniment) are developed following the learning syntax (Joyce et al., 2004). 
The syntax of the personal-cooperative learning model consists of stage I and stage II. The two syntaxes still elaborate on the personal and cooperative models even though in phase I, it emphasizes more on the personal model, and stage II emphasizes more on the social model. Phase I syntax gives flexibility to each student to personally develop their reading ability. The selection of readings is left to students based on their interests. This personalized effort is in accordance with Cannor \& Morrisson's research (2016), which takes into account learning based on students' strengths and weaknesses.

During the first phase of learning with descriptive text, five reading boxes were provided with different titles and reading codes. The color of the box in the reading box and the answer key box is colorful, so it is interesting, and students recognize the headings more quickly. Each box is readable for each title. All readings have been tested at the level of readability at the instructional level. Papatga \& Ersoy (2016) determine the level of readability into three, namely the level of independent, instructional, and frustrated. For the learning process, you should read at the instructional level. In using the reading box, power points were previously displayed on various types of reading boxes, the title of the reading, and how to retrieve, read the reading box, and report the results. The use of reading boxes is intended to identify students' reading abilities, both in terms of reading speed and reading comprehension level. Therefore, a rubric of student reading results has also been prepared.

Phase I syntax is intended so that students understand their abilities and needs for the importance of socialization with friends and the environment. One by one, the students come forward to take readings, take the available tests, and correct the results in pairs with friends to further enhance cooperative attitude and tolerance. After that, report the results to the teacher. PBM looks fun. The teacher also deftly pays attention to student activities, accompanies, and records the results in the rubric of students' reading ability results. Phase I learning that emphasizes the personal model provides motivation to students. The choice of topics that are tailored to the ability, pleasure, and interests of students will have a positive impact and provide motivation for the next learning step (Pečjak et al. 2011; Pandawa et al., 2009; Sonja, 2008).

Phase II syntax is implemented by implementing cooperative learning. There are six phases in the phase II learning syntax. These stages include (1) delivery of goals and motivation of students both personally and in groups, (2) presentation of information, (3) organizing students in discussion groups in accordance with the nature of cooperative learning, (4) guidance in working and learning groups, (5) evaluation, and (6) rewards in terms of cognitive, affective, and psychomotor.

The discussion model implemented was a Jigsaw type, which was divided into three steps, namely (1) Origin group discussion, (2) Expert group discussion, and (3) Origin II group discussion. The division of groups is arranged according to the diversity of students and the principles of cooperative learning (Johnson \& Johnson, 1999; Slavin, 1994; Sugiyanto, 2010). Each group consists of 4-5 students. Male and female students are divided equally. Likewise, the ability to read comprehension of the results of Phase I is distributed evenly to each group.

As stated by Slavin (1994), Johnson \& Johnson (Johnson \& Johnson, 1999), prior to the discussion, the teacher conveys goals, motivates students, as well as provides information about ways of discussion and rules of discussion. Each group was given several instruments, namely group worksheets and individual worksheets, which had to be completed together. Readers who correctly set clear goals and directions before reading will positively influence their abilities (Cheon \& Ma, 2014).

The discussion is active because there is positive interdependence and each student has individual accountability. This method of learning together and alone is consistent with Johnson \& Johnson's model (Johnson \& Johnson, 2002). In the discussion there were no students who strafed roles or did not play a role. Everything has responsibilities. The group task is not completed if there are individual tasks that have not been completed. This is what encourages members to help each other and have a positive dependency.

After presenting the final results of the discussion, the teacher gives appreciation. There are three stars, namely achievement stars, disciplinary stars, and courage stars. Based on the results of reflection with teachers and students, learning with a personal-cooperative model is very beneficial for students because it is not only suitable for smart students, but also suitable for students who are less clever. Giving individual responsibility in collaboration turns out to give students confidence. The weak student feels helped by the fast and the fast feels valued by the weak.

There are four product development. The results of the validation by experts in (1) the conceptual model guide book categorized as very good; (2) Guidelines for learning plans categorized as very good; (3) Teaching Materials for reading comprehension in excellent category; and (4) The Reading Box along with the Answer Key Box is also very well categorized. All products are excellent. However, some suggestions for improvement have been made before the testing phase. 


\section{The testing stage}

Detecting reading comprehension difficulties is challenging because many factors are involved in comprehension ability. Knowledge of the characteristics of each reading comprehension test is essential to the choice of test (Calet et al., 2020). Reading comprehension is not a unique ability that can be assessed by one or more general reading measures or taught by a small set of strategies or approaches(Catts \& Kamhi, 2017). Research questions at the testing stage are answered with experimental research. The experimental class was treated with a personal-cooperative learning-based reading learning model with a Reading Box, while the control class was treated with a classical learning model with the same reading material as in a textbook. The test results show the experimental group has a higher reading comprehension ability compared to the control group.

The experimental class is higher because learning not only applies social models carefully, but also elaborates with personal models. The difference in the mean of the control class and the experimental class is consistent with the research conducted by (Krammer, 2015). Krammer examining the implementation of cooperative learning in learning to read comprehension shows that learning by applying the principles of specifically planned cooperative learning differs significantly from learning with ordinary discussion. The impact of explicit comprehension strategy instruction supported by guided reading and partner reading on reading comprehension (Pilonieta et al., 2019).

There was a unique effect of reading strategies on reading comprehension, and also of reading comprehension on reading strategies (Muijselaar et al., 2017). The effectiveness of the learning model of reading comprehension with a proven superior and effective personal-cooperative model. Thus, learning that pays attention to the rights, willingness, and ability to read each student's understanding and emphasizes the relationship of social interaction with cooperative learning will further enhance students' reading comprehension abilities. What needs to be emphasized is that the elements of the model other than syntax remain to be considered, Jalilifar (2010) in his experimental research provides treatment with Student Team Achievement Divisions (STAD) techniques in the experimental class and conventional instruction techniques in the control class. STAD technique is one of the cooperative learning techniques. The control group with conventional instruction techniques uses regular textbooks usually. The results concluded that STAD was higher and more effective in improving students' reading comprehension abilities. This shows that the discussion should be well designed. Starting from the division of groups, the process of discussion, to the process of presenting results, and giving awards. The study Kavani \& Amjadiparvar (2018) revealed that teachers are encouraged to employ strategy-based instruction to enhance learners' reading comprehension.

\section{CONCLUSIONS}

The reading comprehension personal-cooperative-based learning models are needed to accommodate students 'personal reading abilities and interests and, at the same time, developing students' social skills. It is necessary to create a learning model of reading comprehension based on personal-cooperative which includes five elements of the model, namely developing (1) learning syntax that considers elements (2) social system (atmosphere and norms applicable in learning), (3) principles of reaction (principles that describe how to treat and respond to students), (4) support systems (all means, materials, tools that support learning), and (5) instructional and nurturing effects (direct learning outcomes obtained and the accompanying impact). Stages of the personal-cooperative learning model consist of learning Stage I and Stage II. These two stages of learning use the Reading Box.

The development of reading comprehension personal-cooperative-based learning model is equipped with four products, namely (1) Conceptual Guidebook on Reading Comprehension Learning Model which contains the steps of learning to read comprehension with the personal-cooperative model, (2) Guidelines for Reading Comprehension Personal-Cooperative learning model consisting of syllabus and learning plan that is equipped with material and assessment instruments, (3) Reading Comprehension Learning Materials that contain learning steps with the Reading Box and cooperative learning model, and (4) Reading Box and Answer Key Box used both in Stage I and Stage II.

The results of the feasibility of products of the reading comprehension personal-cooperative-based learning model are declared to be feasible by expert and user validators with excellent category. Personalcooperative based reading comprehension learning model is effective in improving students' reading comprehension ability. 


\section{ACKNOWLEDGMENTS}

Acknowledgments are addressed to the Ministry of Research and Technology of the Republic of Indonesia which have funded this research with PDD grant. Acknowledgments to Universitas Negeri Yogyakarta which have facilitated during the research process. Thanks also go to the team participating during the data collection process until the writing of this article.

\section{REFERENCES}

Bieńkowska, I., Polok, K., \& Sutkowski, A. (2020). Making language teachers creative; teaching english in elementary mainstream schools with integration classes. The New Educational Review, 59(1), 103115. https://doi.org/10.15804/tner.2020.59.1.08

Bozhovich, E. (2009). Zone of proximal development: The diagnostic capabilities and limitations of indirect collaboration. Journal of Russian and East European Psychology, 47(6), 48-69. https://doi.org/10.2753/RPO 1061-0405470603

Calet, N., López-Reyes, R., \& Jiménez-Fernández, G. (2020). Do reading comprehension assessment tests result in the same reading profile? A Study of Spanish primary school children. Journal of Research in Reading, 43(1), 98-115.

Cannor, C. M., \& Morrison, F. J. (2016). Individualizing student instruction in reading: implications for policy and practice. Policy Insights from the Behavioral and Brain Sciences, 3(1), 54-61. https://doi.org/10.1177/ 2372732215624931

Catts, H. W., \& Kamhi, A. G. (2017). Prologue: Reading comprehension is not a single ability. Language, Speech, and Hearing Services in Schools, 48(2), 73-76.

Cheon, H. J., \& Ma, J. H. (2014). The effects of reading purpose on reading comprehension and perceived difficulty. English Teaching, 69(2), 51-69. http://journal.kate.or.kr/wpcontent/uploads/ 2015/01/kate_69_2_3.pdf

Coleman, J., \& Klapper, J. (2005). Effective learning \& teaching in modern languages. Routledge.

Crawley, S. J., \& Mountai, L. (1995). Strategies guiding content reading (2nd ed.). Allyn and Bacon.

Creswell, J. W. (2008). Educational research: Planning, conducting, and evaluating quantitative and qualitative research (3rd ed.). Pearson Education, Inc.

Eker, C. (2014). The effect of teaching practice conducted by using metacognition strategies on students' reading comprehension skills. International Online Journal of Educational Sciences, 6(2), 269-280. https://doi.org/iojes. 2014.02.002

Gall, M. D., Borg, W. R., \& Gall, J. P. (2003). Educational research: an introduction. Pearson Education, Inc.

Hidayah, R. (2012). Literasi di rumah berpengaruh kuat terhadap pemahaman anak dalam membaca. Universitas Gadjah Mada, Yogyakarta.

Jalilafar, A. (2010). The effect of cooperative learning techniques on college students' reading comprehension. System, 38(1), 96-108. https://doi.org/10.1016/j.system.2009.12.009

Johnson, D., \& Johnson, R. (1999). Making cooperative learning work. Source: Theory into practice. Building Community through Cooperative Learning, 38(2), 67-73. http://www.jstor.org/stable/1477225

Johnson, D., \& Johnson, R. (2002). Learning together and alone: overview and metaanalysis. Asia Pacific Journal of Education, 22(1), 95-105. https://doi.org/10.1080/0218879020220110

Joyce, B., Weil, M., \& Calhoun, E. (2004). Models of teaching. Boston: Pearson.

Karl, S. (2009). Learning together and alone: cooperation, competition, and individualization. NACTA Journal, 23(3), 23-26. https://www.jstor.org/ stable/ 43763555

Kavani, R., \& Amjadiparvar, A. (2018). The Effect of Strategy-Based Instruction on Motivation, SelfRegulated Learning, and Reading Comprehension Ability of Iranian EFL Learning. Cogent Education, 5(1), 1-7. https://doi.org/10.1080/2331186X.2018.1556196

Kissau, S., \& Hiller, F. (2013). Reading Comprehension Strategies: an international comparison of teacher preferences. Research in Comparative and International Education, 8(4), 437-454. https://doi.org/10.2304/rcie.2013.8.4.437

Krammer, M. (2015). Effects of cooperative learning methods in German language Arts on reading ability and social behavior of High School Students. Journal of Studies in Education, 5(4), 1-22. https://doi.org/10.5296/ jse.v5i4.8192

Lehr, K. (2013). Instruction reading comprehension. Kansas: The University of Kansas.

Lie, A. (2010). Cooperative Learning. Jakarta: Grasindo.

May, F. B., \& Rizzardi, L. (2002). Reading as communication (6th ed). Prentice Hall.

Mota, R. (2014). Innovation and independent learning in Basic Education. Ciência e Natura, 36(1), 121-129. https://doi.org/10.5902/2179460X13196 
Muijselaar, M. M. L., Swart, N. M., Steenbeek-Planting, E. G., Droop, M., Verhoeven, L., \& de Jong, P. F. (2017). Developmental Relations between Reading Comprehension and Reading Strategies. Scientific Studies of Reading, 21(3), 194-209.

Mustofa. (2012). Indonesia people reading habit is very low: How libraries can enhance the people reading habit. Jurnal Institut Pertanian Bogor, 1-10. https://docplayer.net/38162063-Indonesian-peoplereading-habit-is-very-low-how-libraries-can-enhance-the-people-reading-habit.html

Pandawa, N., Hairudin, \& Sakdiyah, M. (2009). Pembelajaran membaca. Jakarta: Depdiknas.

Papatga, E., \& Ersoy, A. (2016). Improving reading comprehension skills through the SCRATCH program. International Electronic Journal of Elementary Education, 9(1), 124-150. https://doi.org/10.1598/RT.61.8.1

Patel, B. (2013). Social interaction model. International Journal for Research in Education, 2(5). https://raijmronlineresearch.files.wordpress.com/2017/07/8_30-32-bhavin-h-patel.pdf

Pearman, C. (2008). Independent reading of CD-ROM storybooks: measuring comprehension with oral retellings. Journal the Reading Teacher, 61(8), 594-602. https://doi.org/10.1598/RT.61.8.1

Perfetti, C., \& Stafura, J. (2014). Word knowledge in a theory of reading comprehension. Scientific Studies of Reading, 18(1), 22-37. https://doi.org/10.1080/10888438.2013.827687

Pilonieta, P., Hathaway, J., Medina, A., \& Casto, A. (2019). The Impact of Explicit Comprehension Strategy Instruction on First- and Second-Grade At-Risk Students. Journal of Education, 199(3), 128-141.

Sadeghi, R., \& Moslehpour, S. (2014). Comparison Classical Method of Education and Modern Web-Based Distance Learning System (WBDLS). International Journal of Modern Engineering, 8(1), 128-142.

Slavin. (1994). Learning to cooperate, cooperating to learn. Plenum Press.

Sonja. (2008). Reading motivation and reading efficiency in third and seventh grade pupils in relation to teacher' activities in the classroom. Journal Studia Psychologica, 50(2), 147-165.

Sugiyanto. (2010). Model-model pembelajaran inovatif. Jakarta: Yuma Pustaka.

Sukmadinata, N. (2012). Metode penelitian pendidikan. Bandung: Remaja Rosdakarya.

Tavakoli, M. (2013). The effect of using print media on children's L2 literacy Development: a longitudinal study. Journal of Language Teaching and Research, 4(3), 570-578. https://doi.org/ 10.4304/jltr.4.3.570-578

Yildirim, K., Cetinkaya, F. C., Ates, S., Kaya, D., \& Rasinski, T. (2020). Testing the KAPS Model of Reading Comprehension in a Turkish Elementary School Context from Low Socioeconomic Background. Education. Education Science, 10(4), 90-98. 